\title{
The Research of Quality Culture for Nationalities Colleges
}

\author{
Ren Changhong ${ }^{1, a}$ and Cong Xingling ${ }^{1, b}$ \\ ${ }^{1}$ Deans' office of Dalian Nationalities University, Dalian 116600. Liaoning Province \\ arch@dlnu.edu.cn, b1034493681@qq.com
}

Keywords: Nationalities College; Quality Culture; Internal Quality Assurance System

\begin{abstract}
The college quality culture is the sum of the quality philosophy, quality image, quality system and quality behavior, which are relatively stable, generally recognized and gradually formed in the long-term education and teaching practice. It's a college sub-culture that takes quality increasing as fundamental. The quality culture for nationalities college is constructed by 4 aspects, including spiritual culture, material culture, system culture and behavior culture. The realization of nationalities college internal quality assurance system implicated the production of college quality culture, while the latter is heart and soul of the construction, the fundamental way and soft means of nationalities college internal quality assurance system. The nationalities college should abide by the internal regulations of quality culture and educate and develop quality culture system that adapted to its own settlements and characteristics.
\end{abstract}

\section{Introduction}

The quality is the eternal topic in area of education. With the increasingly expansion of higher education scale and diversification of stakeholders, the problem of higher education quality is concerned by the whole society. Many institutions of quality management and security are set up, and massive quality management and assurance activities are carried out. It plays a positive role for colleges and universities to improve the quality of higher education through establishing teaching quality assurance system and improving the internal quality guarantee mechanism. But if we focus on system and methods as well as procedures and technology too much in teaching quality management practice, it will fall into predicament, and therefore difficult to ensure its effect. So, researchers should notice the limit of technical means. We introduce the idea and thought about quality culture when we build the college guarantee system, in the same time we advocate to change mind and focus on the internal world of college faculty and students instead of technological means of quality management and security. We also start to build and improve the long-term mechanism of teaching quality. The development of quality culture of nationalities universities is related to the future and quality of national high education, which should be the important subject for nationalities college educators.

\section{The Concept and Connotation of Quality Culture for Nationalities Colleges}

The concept of quality culture, originated from modern enterprise management, mainly refers to the way of thinking, moral concept, value orientation, the management idea, rules and regulations and other combined cultural factors which are closely related to enterprise product quality. Barry believes that the quality culture is a kind of comprehensive and overall concept; it absorbs people's common knowledge, attitude, values and beliefs, and shifts it to another advocate quality model [1]. Saraph and Sebastian said quality culture is a collective idea and understanding about quality values of an organization in developing its own ability to adjust the external environment and dealing with internal affairs [2]. Fischer-Bluhm equates quality culture with internal quality management [3]. EUA defined the quality culture as an organization culture that dedicated to permanently improve the quality in the "culture of quality project" research report [4]. The famous American management thinker Chris points out: For a long time, people think that quality means good, luxury, brightness, or component. However, the quality is not a measure of product quality; we can't use ordinary, very 
good, superior, and other words to describe it. Quality means that product accords with a requirement which conforms to the objective requirement of the customers and the market, rather than the enterprise's own subjective definition of 'good', this is the whole meaning of it [5].

The above views are instructive for us to understand the quality culture. We can consider that the quality culture of colleges and universities is a kind of subculture to permanently improve the quality of universities. It not only directly shows as colleges and universities teaching quality, management quality, work quality, also extends to the service quality, environmental quality, etc. It embodied the overall quality of colleges and universities. Quality culture is equal to the internal quality of soft management in colleges and universities. It condenses school leaders and faculty by faith, hope and promise. It guides teachers and students to what to do and what to achieve in the process of quality education form through the views of talent, value and quality. At present, the high esteemed statement for concept of quality culture of colleges and universities is: "quality culture of colleges and universities is gradually formed in the long-term education practice, it's relatively stable and is generally agreed as the combination of the ideas, values, images, systems and specifications and materialized forms of quality" [6].

Quality culture for nationalities colleges, as a kind of management and organizational culture, originated from the education practice which in turn affects the education practice. It has the universality of colleges and universities, distinct national character, and also has a unique school's personality; all of these are related to the school's history and positioning. It decides the quality of colleges and universities value, quality awareness and quality behaviour. Ideal quality culture of nationalities colleges, as a kind of subculture which takes the quality as the core and take the education quality improving as the fundamental pursuit, is the quality culture which pays attention to the social responsibility of nationalities colleges, clearly knows the objectives and positioning of the ethnic education, attaches great importance to the national differences of students, takes all the students as the core, pays attention to the national communication, attaches importance to the quality of the students' participation and satisfaction. It emphasizes guiding the teaching work with the idea of total quality management and behavior, guiding the whole teaching process with the concept and behavior which is object oriented, promoting teachers, curriculum, professional, the connotation of the school overall development with concept and behaviour which develop continuously to ensure all the cultivating talents of ethnic groups with relevance, conform to the state and social demand, comply with the employer's requirements. A massive historical sense of responsibility and national responsibility culture can promote the teaching quality of the nationalities colleges to ascend effectively.

\section{The History and Present Situations of Research for Quality Culture for Nationalities Colleges}

European quality organization held the 33rd annual meeting in 1989, it pointed out that "the total quality management should emphasis on the development of cultural instead of management of the top manage leaders personally and all the participation " [7]. Mass culture researches caught the attention of the world. In 2002, the European university association began to implement the "culture of quality engineering", gave the meaning of interoperability to the culture of quality. In 2009, the European university association and other alliance cooperation carried out the "testing engineering institutions of higher education quality culture", made clear the definition of mass culture [8]. In recent years, colleges and universities abroad show social public responsibility by fostering dynamic internal quality culture, and achieved good effect in enhancing the autonomy of colleges and universities. Researchers stressed that quality culture of colleges and universities is the foundation and core of the national and international quality assurance system, all of the quality assurance system should be based on perfect quality culture of college. INQAAHE (network organization of higher education quality assurance institutions) thinks that establishing consciousness of a quality culture in colleges and universities is important to build consensus on quality management system. Bologna follow-up group pointed out that "dedicated to the most basic motivation of the higher quality must come from the college itself - their internal quality assurance system and quality culture" 
[9]. Denmark scholar Lee Harvey pointed out that the establishment of internal quality system is not equal to establish the quality culture. Colleges and universities as the main body of quality assurance, need clear plans and related procedures, to ensure the education quality and standards, and strive to build the quality culture [10].

Compared with foreign universities, the research about quality culture of colleges and universities in China has fallen behind. In the 20th anniversary of the convention about national implementation of total quality management in June 1999, Wang Di zhi from University of Shanghai put forward clearly "foster culture of quality, changing teaching idea" [11]. Since then, the concept of quality cultural entered into the Chinese education field with total quality management concepts, but it developed slowly in the following ten years. In January 2013, the Chinese institution of higher education evaluation branch put forward to "establish a sound and perfect quality guarantee system construction, promote the quality culture construction in colleges and universities" explicitly in academic annual conference. The participants agreed that "quality culture is the driving force for the development of the higher education connotation and application of the power of culture to cultural consciousness to affect the social system and higher education system, to guarantee the quality of higher education system" [12]. In September 2014, at the higher education quality assurance international conference, Assessment centre in the ministry of education advocates to cultivate quality of university culture, to make quality assurance to be a conscious act, and then concise it into a culture of quality, at last sublimate it into a kind of university culture.

Compared with foreign universities, China's nationalities colleges have fallen behind in the research of national quality culture of colleges and universities as well. Nationalities colleges are mostly built in national regions. Due to the imbalance of the development, the problem which universities put excessive emphasis on hardware construction and despises software culture construction exists. Nationalities colleges' internal quality management is basically limited to administrative category, and they focus on the methods and tools, processes and technology, hierarchy and system, and seldom touches the quality of education culture core. The very little literature is limited in quality assurance technology level or campus culture level. Only make education quality become the spirit and idea of national education and national educators, make education quality management become a quality management strategy from a kind of management or technique, make the internal teaching quality control and guarantee behaviour become a voluntary teaching quality culture, can we improve the quality of the national higher education in our country truly.

\section{The Construction Components and Their Relations of Quality Culture for Nationalities Colleges}

Colleges and universities are essentially conceptual organizations and cultural institutions, different quality management of colleges and universities possess the distinctive quality culture. Usually the quality culture of colleges and universities includes the spiritual culture, system culture, material culture and behavior culture [13]. The spiritual culture is implicit, it permeates in thoughts and the heart of all the faculty and staff. And it is a kind of inner charisma. Spiritual culture, as the foundation and source of quality culture, is the core and the ultimate goal of quality culture, it mainly includes moral values, the school's educational philosophy, guidelines, the educational orientation and target and so on, which all the school teachers and students agree. System culture is the important aspect of the quality culture in colleges and universities, it's the system, norms and the rules made and executed by the colleges and universities to realize their talent training and quality assurance targets. It is the binding normative culture for quality behavior of staff, mainly includes the quality assurance system, quality standard system, quality management files and quality evaluation, evaluation and incentive system, etc. Material culture is the material part of the quality culture of colleges and universities, it condenses in physical facilities in colleges and universities, it's the external part of quality culture which includes the architectural style, the campus environment as well as the perceived cultural facilities that has a material entity, such as educational environment with school 
characteristics and educational techniques, etc. Behavior culture is the important explicit culture; it is the habitual set and behavior patterns of the members in quality activities, including teachers' teaching behavior, the students' learning behavior and management personnel' manage behavior, etc.

In the complete system of quality culture in universities, material culture, system culture, spirit culture, behaviour culture has mutual influence and interaction. Spiritual culture is the core content and the highest state of quality culture, and also is the ultimate goal of quality culture construction, it provides ideological basis to system culture, behaviour culture and material culture. System culture embodies the top design of quality culture, constrains and regulates the construction of spiritual culture, behaviour culture and material culture. Behaviour culture is the comprehensive manifestation of quality culture, reflects the spirit culture, material culture, system culture and other factors. Material culture is the external performance and carrier of quality culture, provides material basis for spiritual culture and institutional culture.

Nationalities colleges have their distinctive service orientation and position during its early years, that's facing the needs of ethnic minorities and national regions and serving minorities and ethnic minority areas. They condense the distinctive national characteristics in the school on the objects and even a brick, influenced generations of educators and the students. This congenital advantage is the confidence and spiritual power of nationalities colleges for cultivating and developing the quality culture. Names of nationalities colleges, the main building of the campus and other ethnic customs reflect national culture and national spirit, that's an important support of material culture. The system construction of nationalities colleges embodies the unity and fusion of ethnic groups, represents a unified multi-ethnic tolerance. Campus culture activities between teachers and students in nationalities colleges have strong national colours, create a unique cultural atmosphere. Teachers in nationalities colleges have strong sense of responsibility, it's the main embodiment of behavior culture by teaching students of all ethnic groups with different way according to their aptitude,. In the midst of this, material culture and behavior culture belong to shallow culture, system culture and spiritual culture are the deep culture. These four aspects are associated, constrained and penetrated with each other, they constitute the quality culture of nationalities colleges and play the role of guidance, cohesion and constraints in the nationalities colleges in the construction of internal quality assurance system.

\section{The Relationship between Quality Culture and Internal Quality Assurance System in Nationalities Colleges}

The quality culture of nationalities colleges is the core and soul of internal quality assurance system in nationalities colleges, and is the basic way to improve internal quality assurance system constantly. Internal quality assurance system in colleges and universities is the self-monitoring, self assessment, self improving and self developing quality management system to ensure the quality of education. In internal quality assurance system in colleges and universities, the key executives are people; the most fundamental mechanism of action is the culture. Educating and teaching of all efforts in colleges and universities can achieve the desired effect only by the faculty's actively and consciously participation. This action can become a way of life or habit only when the quality requirements put into the common values of all the members, and internalizes as the consciousness and the pursuit for all members, and at last it can become their self-conscious. Only when the national cohesion of the staff and students in colleges and universities inject national responsibility in their blood, can quality culture effectively inspire the cohesion and centripetal force, then make it become the soul of quality assurance, at last realize the pursuit of national high internal quality.

The implementation of internal quality assurance system has prompted the birth of quality culture in nationalities colleges. For a long time, the pursuit of teaching quality in nationalities colleges is not high. Servicing ethnic minorities and national regions doesn't mean lowing talents cultivation standard of national higher education. The quality culture of nationalities colleges is embedded as a pursuit of the quality of teaching in colleges and universities in their process of ascension. A national value work, if insist on for three years, can form as characteristics, and if adhere to ten years, can form 
as culture. Nationalities colleges have attached savings for years with governments' great support, it has become the inside information of its national culture. The implementation process of the internal quality assurance system as a conception, consciousness and behaviour of cultivation process, needs to keep accumulating and precipitating. Nationalities colleges should release self bondage on the quality standard, and shouldn't lower their standards on the quality of teaching. They also should improve their standards on service for students, and establish the centre position of the teaching quality truly. They also should improve the quality consciousness of all staff, as well as their concept of quality and quality management skill. It's important to motivate staffs' attention in the national higher education, to improve their attention of national education quality, to make the quality form a concept and spirit, and to realize self-management, self-improvement in the work constantly, to put the consciousness of quality management into the school work of teaching management, to strengthen the national sense of belonging, a sense of pride and sense of mission by strengthening the cohesion the centripetal force and vitality of the school. And then the quality culture with national characteristics can act from free to consciousness in the effective implementation of internal quality assurance system.

\section{Conclusion}

The research about quality culture has the vital significance to the practice and construction of internal quality assurance system in nationalities colleges. Nationalities colleges should stimulate their cultural genes, cultivate characteristic quality culture, and make the teaching quality guarantee system, internal quality assurance mechanism to play a bigger role in the development of nationalities colleges under the lead of culture.

\section{Acknowledgements}

This work is financially supported by Education Teaching Reform Project of Undergraduate Course of Common Colleges and Universities in Liaoning Province(UPRP20140949) and is the Subject of Education Decision-making Consultation in Dalian Nationalities University.

\section{References}

[1] G. Berry: Leadership and the Development of Quality Culture in Schools. International Journal of Educational Management Vol.11,No.2 (1997)

[2] J.V. Saraph and R.J. Sebastian: Developing a Quality Culture. Quality Progress Vol.9, (1993).

[3] K. Fischer-Bloom: Instruments for Raising Quality Culture in a Network of Universities European University Association (2007).

[4] Liu Zhiyuan: Thinking of improving the quality of the higher engineering education based on the bologna process quality assurance. Higher agricultural education Vol.264,No.6 (2013),p.121-124.

[5] Wang Shanshan: Series of study about the quality culture of higher education. Explore of Education Vol.241,No.7 (2011),p. 21-23.

[6] Luo Ruguo and Wang Shanshan: Erroneous zone and the quality culture construction in universities. Modern education management Vol.10 (2013),p.30-36.

[7] Wu Zhi and Wang Delin: Strengthen quality culture construction; improve higher education quality assurance system. Journal of south China university of technology (social science edition) Vol.12,No.2 (2010),p.80-82.

[8] Du Guiying: New progress in higher education quality management: quality culture research. Journal of Hebei normal university Vol.14,No.3 (2012),p.17-20. 
[9] Zhou Mansheng and Chu Aijing: Achievements, challenges and prospect-the review of the development of European area of higher education quality assurance review in the past ten years. Education Review in Beijing university Vol.4 (2011),p.118-131.

[10] Lin Mengquan, Tang Zhenfu and Du Zhifeng: The issues and development trends about international higher education quality assurance in recent years-network organization for institutions of higher education quality assurance (INQAAHE). China higher education Vol.11 (2013),p.60-62.

[11] Wang Dizhi: The proceedings of the 20th anniversary of the establishment of the national implementation of total quality management conference. China quality management association Vol. A (1999).

[12] Wang Yuan, Ma Jiani and Du Ruijun: Quality culture, faculty development, undergraduate teaching assessment and quality guarantee system construction -The academic review of Chinese institution of higher education evaluation branch on 2012 annual meeting. China's higher education evaluation Vol.2 (2013),p.62-67.

[13] Zhu YongJiang: Quality culture: the soul of the construction of internal quality guarantees system in colleges and universities. Modern education science Vol. 4 (2012),p.98-101. 